\title{
Epiphyte colonisation of fog nets in montane forests of the Taita Hills, Kenya
}

\author{
Åsa Stam ${ }^{1, *}$, Xiaolan $\mathrm{He}^{2}$, Ulla Kaasalainen ${ }^{3}$, Mikko Toivonen ${ }^{4}$, Johannes \\ Enroth $^{1,2}$, Matti Räsänen ${ }^{5}$ \& Jouko Rikkinen ${ }^{1,3}$
}

1) Organismal and Evolutionary Biology Research Programme, Faculty of Biological and Environmental Sciences, P.O. Box 65, Fl-00014 University of Helsinki, Finland ( ${ }^{*}$ corresponding author's e-mail: asa.stam@helsinki.fi)

2) Finnish Museum of Natural History, P.O. Box 7, Fl-00014 University of Helsinki, Finland

3) Department of Geobiology, University of Göttingen, Goldschmidtstraße 3, D-37077, Göttingen, Germany

4) Department of Computer Science, P.O. Box 68, Fl-00014 University of Helsinki, Finland

5) Department of Geosciences and Geography, P.O. Box 64, Fl-00014 University of Helsinki, Finland

Received 20 Jan. 2020, final version received 18 May 2020, accepted 18 May 2020

Stam Å, He X., Kaasalainen U., Toivonen M., Enroth J., Räsänen M. \& Rikkinen J. 2020: Epiphyte colonisation of fog nets in montane forests of the Taita Hills, Kenya. - Ann. Bot. Fennici 57: 227-238.

The dispersal ecology of tropical non-vascular epiphytes has rarely been experimentally investigated. We studied epiphyte colonisation on $1 \times 1 \mathrm{~m}$ polyethene nets placed for four years at seven sites at different elevations in montane forests in the Taita Hills, Kenya. During the first year the nets were also used to measure fog deposition. We predicted that differences in growth conditions would affect colonisation and subsequent growth of non-vascular epiphytes and result in clear differences in epiphyte cover and biomass, and community composition among sites. After four years the nets were taken down for determination of epiphyte cover and biomass. The diversity of established liverworts and macrolichens was also examined. Many liverwort and macrolichen species established diverse communities on the nets placed in the moist upper-montane zone. This was in contrast with the situation in the drier lower-montane zone where only green algae and crustose lichens were able to colonise most nets. Light intensity was an important determinant of epiphyte community composition, with liverworts dominating on nets under closed forest canopies and lichens dominating at more open sites. Atmospheric moisture was also important, with lichens benefiting from abundant fog deposition at open and windy sites. The dry weight of epiphytes (per unit area) on lichen-dominated nets was greater than on liverwort-dominated nets, while the highest cover was generally observed on liverwort-dominated nets. Our results demonstrate that polyethylene nets can be effectively used to study colonisation of non-vascular epiphytes as well as the abiotic and biotic factors controlling epiphyte colonisation and community composition in tropical forests. The liverworts Acanthocoleus chrysophyllus and Diplasiolejeunea kraussiana were new additions to the Kenyan bryophyte flora. 


\section{Introduction}

Non-vascular epiphytes (bryophytes, lichens) gain most of their water and nutrients directly from the atmosphere and are known to be sensitive to environmental change (Jácome et al. 2011, Stam et al. 2017, 2019). Especially in tropical montane forests they play an important role in intercepting and storing of water (Veneklaas et al. 1990, Ah-Peng et al. 2017, Porada et al. 2018), in nutrient cycling, and in providing diverse habitats and serving as food for animals, especially invertebrates (Gradstein 1992, Bader 2013).

Tropical mountain cloud forests (TMCFs) are often very rich in both non-vascular and vascular epiphytes (Bruijnzeel et al. 2010, Jácome et al. 2011). Non-vascular epiphytes can grow as thick mats on tree trunks, as smaller patches on branches and twigs, and even on the leaf surfaces of vascular plants as epiphylls. Because of their unique climatic characteristics, i.e., high relative humidity and low irradiance due to high cloud cover and frequent mist (Foster 2001, Bruijnzeel et al. 2010), TMCFs are predicted to suffer from effects of global climatic change, especially from warming and drying (Sala et al. 2000, Foster 2001, Malcolm et al. 2006). Despite the obvious importance of non-vascular epiphytes for water conditions in TMCFs, many basic aspects in epiphyte ecology remain poorly known (Chen et al. 2010, Slack 2011, Gómez González et al. 2017). Environmental changes can be assessed by mapping and monitoring the distribution and abundance of non-vascular epiphytes (Szczepaniak \& Biziuk 2003, Jácome et al. 2011). Transplant experiments have also been used in studying basic ecology of non-vascular epiphytes (e.g. McCune et al. 1996, Stam et al. 2017, 2019), but long-term monitoring studies have rarely been carried out, especially in the tropics (Gignac 2001, Jácome et al. 2011). Very few experimental studies addressed the dispersal ecology of tropical non-vascular epiphytes or compared the colonisation ability of different groups of epiphytes within the same forest environment (Sanders \& Lücking 2002, Hutsemeker et al. 2008, Acuña-Tarazona et al. 2015). Therefore, our goal was to collect experimental data on factors that affect the colonisation ability and hence also the distribution of non-vascular epiphytes in tropical forests.

We studied epiphyte colonisation on $1 \times 1 \mathrm{~m}$ polyethene nets placed for four years in montane forests in the Taita Hills, Kenya. The nets were set at seven study sites along an elevational gradient. During the first year the nets were also used for measuring fog deposition (Räsänen et al. 2018). We expected that contrasting growth conditions would affect colonisation and subsequent growth of non-vascular epiphytes and lead to clear differences in epiphyte cover and biomass, and in community composition among sites. Our hypotheses were as follows: (1) There would be clear differences in the cover, biomass, and community composition of non-vascular epiphytes on nets placed in moist upper montane forests and drier lower montane forests, with the former supporting both higher epiphyte diversity and biomass. The observed differences would be expected to also reflect contrasting habitat requirements of different groups of epiphytes, with epiphytic liverworts markedly benefiting from the cool and humid conditions in the forests at higher elevations. (2) There would also be marked differences between the nets placed under dense forest canopies and at more open sites within the different habitat types. Again, the predicted differences would also reflect the contrasting habitat requirements of different groups of epiphytes, with bryophytes showing high diversity and abundance on shaded nets and lichens on nets at more open sites.

\section{Methods}

The study was conducted in the Taita Hills $\left(3^{\circ} 25^{\prime} \mathrm{S}, 38^{\circ} 20^{\prime} \mathrm{E}\right)$, which represent the northernmost extension of the Eastern Arc Mountains in SE Kenya. The Taita Hills rise abruptly from the surrounding dry plains at ca. 600-1000 m a.s.l. to a series of mountain ridges, reaching $2208 \mathrm{~m}$ a.s.l. at the highest peak, Mt. Vuria. The upper slopes of the mountains benefit from moisture brought by the trade winds and capture enough of it to sustain moist evergreen montane forests. The moist and relatively cool climate provides favourable conditions for the development of species-rich bryophyte and lichen communities 
and considerable epiphyte biomass (Enroth et al. 2013, 2019, Stam et al. 2017, 2019).

The Taita Hills experience long rains between March and May, and a shorter rainy season between November and December. The average annual rainfall on the plains is about $500 \mathrm{~mm}$, while the mountains receive over $1000 \mathrm{~mm}$ of rain annually (Pellikka et al. 2009, Räsänen et al. 2018). Three of our study sites were in the northern part of Ngangao Forest, a relatively dry lower montane cloud forest covering the slopes of a N-S-oriented mountain ridge (Table 1). The remaining four sites were on the upper slopes of Mt. Vuria (Table 1). The forests at this site represent badly degraded upper montane cloud forest (Aerts et al. 2011, Thijs 2015). They have been under strong human influence (incl. felling and grazing), but receive relatively abundant moisture from low-lying clouds and fog, and are hence much wetter than the forests in Ngangao or other sites in the Taita Hills. To study the effect of light, wind, fog and humidity on the cover and biomass of the epiphytes on the nets, study sites in each forest type were roughly divided into 'shady' and 'open' habitats, depending on overall canopy shading at each site. More information on the forest structure and environmental conditions on Mt. Vuria and Ngangao, is given in Thijs (2015), Stam et al. (2017), and Räsänen et al. (2018).

To collect data on epiphyte colonisation and growth, as well as on the quantity and temporal patterns of fog deposition in the Taita Hills, a total of 20 green $1 \times 1 \mathrm{~m}$ polyethene nets (mesh size about $1 \mathrm{~cm}$; Fig. 1) were installed at 10 study sites in early October 2013 and left there for four years. An identical $1 \mathrm{~m}^{2}$ net was attached to each side of a metal frame $(1.5 \mathrm{~cm}$ thickness), and each frame was positioned at $1 \mathrm{~m}$ height aboveground so that one side was facing prevailing winds at the location. In Ngangao, the study sites formed a linear gradient over the mountain ridge. Originally, there had been six study sites at that location, but half of them were destroyed during the study. Two study sites on Mt. Vuria were under a closed forest canopy and two were in small forest clearings. Between October 2013 and September 2014, the annual rainfall on Mt. Vuria was $1257 \mathrm{~mm}$ and in Ngangao $841 \mathrm{~mm}$. The fog deposition (water equivalent) during a 6-month period in 2013 on Mt. Vuria was $1078 \mathrm{~mm}$ and in Ngangao $338 \mathrm{~mm}$. The mean annual temperatures were $13.9^{\circ} \mathrm{C}$ and $17.0^{\circ} \mathrm{C}$ on Mt. Vuria and Ngangao, respectively [for more climatic variables, see table 1 in Stam et al. (2019)]. Fog deposition under the forest canopy was $60 \%$ smaller than at more open sites (Table 1).

In January 2018, after four years in the field, the nets (henceforth called plots where appropriate) were taken down and air dried. In the laboratory the central section of each net was cut into $16,20 \times 20 \mathrm{~cm}$ subplots $(n=224)$ for determination of epiphyte cover and biomass. The outer surface of each subplot was photographed

Table 1. Site elevations, mean monthly fog amounts (water equivalents; $\mathrm{mm}$ per month), and the total amounts of fog collected from the seven study sites between 1 October 2013 and 30 April 2014 (water equivalent; mm per 6 months).

\begin{tabular}{llll}
\hline Site $\quad$ Elevation (m a.s.I.) & \multicolumn{1}{c}{ Fog (mm, water equivalent) } & Coordinates (DMS) \\
\cline { 3 - 4 } & monthly mean six-month total & \\
\hline
\end{tabular}

\begin{tabular}{|c|c|c|c|c|}
\hline \multicolumn{5}{|c|}{ Ngangao } \\
\hline $\mathrm{N} 2 \mathrm{~F}^{*}$ & 1864 & 10 & 71 & $3^{\circ} 21^{\prime} 28.638^{\prime \prime} \mathrm{S}, 38^{\circ} 20^{\prime} 20.677^{\prime \prime} \mathrm{E}$ \\
\hline $\mathrm{N} 4 \mathrm{O}$ & 1874 & 50 & 350 & $3^{\circ} 21^{\prime} 32.331^{\prime \prime} \mathrm{S}, 38^{\circ} 20^{\prime} 28.215^{\prime \prime} \mathrm{E}$ \\
\hline $\mathrm{N} 6 \mathrm{O}$ & 1776 & 85 & 592 & $3^{\circ} 21^{\prime} 35.694^{\prime \prime} \mathrm{S}, 38^{\circ} 20^{\prime} 39.951^{\prime \prime} \mathrm{E}$ \\
\hline \multicolumn{5}{|c|}{ Mt. Vuria } \\
\hline V10 & 2176 & 50 & 352 & $3^{\circ} 24^{\prime} 50.580^{\prime \prime} \mathrm{S}, 38^{\circ} 17^{\prime} 29.400^{\prime \prime} \mathrm{E}$ \\
\hline V2F & 2180 & 17 & 120 & $3^{\circ} 24^{\prime} 50.472^{\prime \prime} \mathrm{S}, 38^{\circ} 17^{\prime} 31.200^{\prime \prime} \mathrm{E}$ \\
\hline V3F & 2074 & 19 & 130 & $3^{\circ} 24^{\prime} 44.244^{\prime \prime} \mathrm{S}, 38^{\circ} 17^{\prime} 31.160^{\prime \prime} \mathrm{E}$ \\
\hline V4O & 2066 & 68 & 476 & $3^{\circ} 24^{\prime} 44.964^{\prime \prime} \mathrm{S}, 38^{\circ} 17^{\prime} 39.840^{\prime \prime} \mathrm{E}$ \\
\hline
\end{tabular}

\footnotetext{
* Because the fog collector stopped working at N2F at an early stage, the amount of fog for that site was estimated using amounts collected at other sites as follows: $\mathrm{N} 2 \mathrm{~F}=\mathrm{N} 3 \mathrm{~F} / \mathrm{N} 4 \mathrm{O} \times \mathrm{N} 1 \mathrm{O}$.
} 

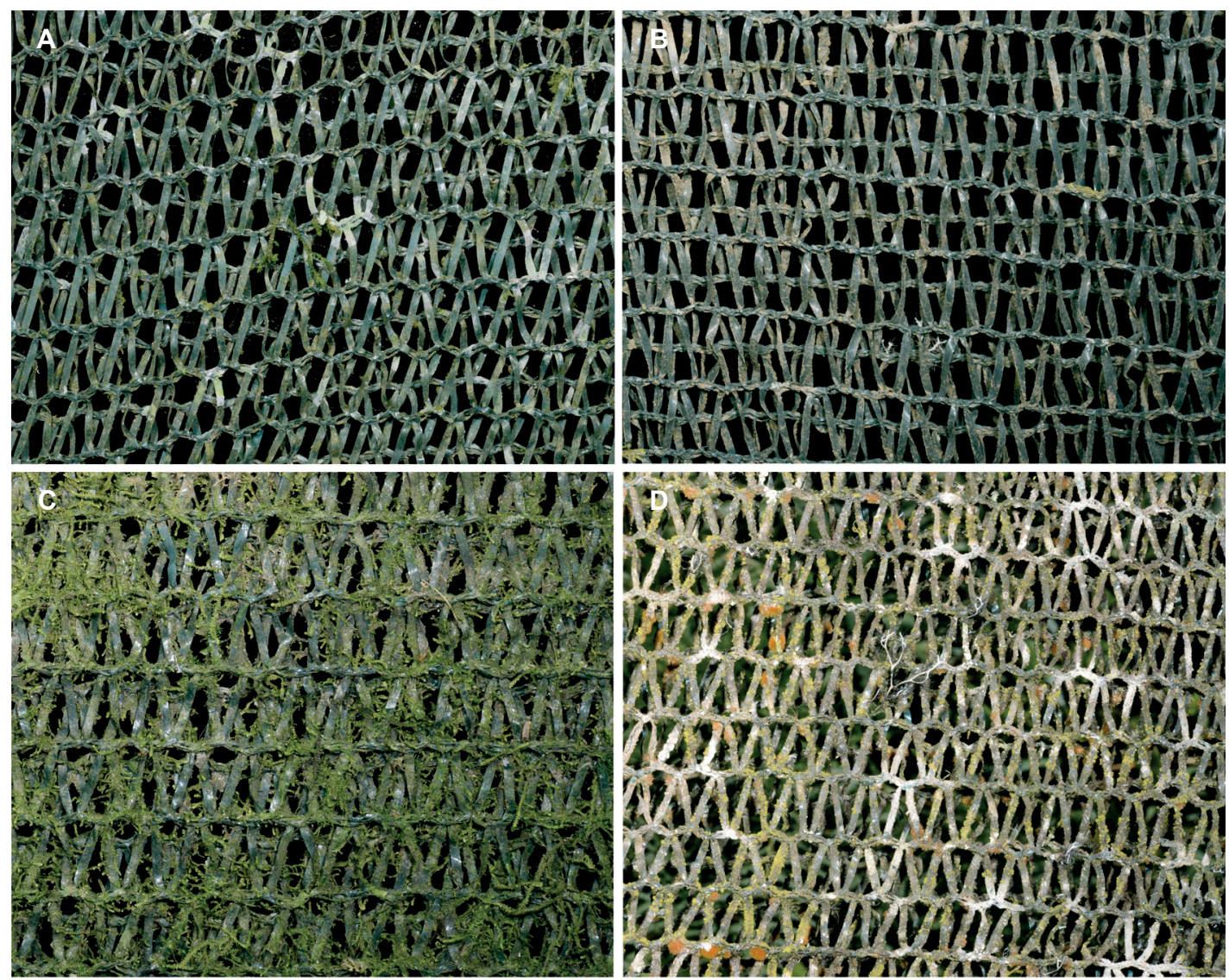

Fig. 1. Images of nets after four years photographed in situ from the upwind side. - A: Lower montane forest, dense canopy (N2F). - B: Lower montane forest, open site (N6O). - C: Upper montane forest, dense canopy (V2F). - D: Upper montane forest, open site (V1O).

with a hyperspectral and RGB cameras, and each subplot was weighed on an analytical scale to the nearest $0.001 \mathrm{~g}$. Finally, mosses, liverworts and macrolichens growing on three randomly selected subplots from each net were identified under dissecting and compound microscopes.

To determine epiphyte biomass, the weight on a $20 \times 20 \mathrm{~cm}$ clean net was subtracted from the weight of the epiphyte-covered subplot.

To determine epiphyte cover, the subplot images were analysed assuming that everything else in the image except the empty background and the clean plastic net (value 0) represented epiphyte cover. Segmentation of the cover was done using two $k$-nearest neighbor $(k$-NN) classifiers, one using the Euclidean distance and the second using the correlation coefficient as the distance function. A third number was the intersection of the segmented results of the $k$-NN classifiers, which was then used for determining cover values. Both $k$-NN classifiers were trained with the same training set of 2313 reference spectrum samples picked from the data set. Each reference spectrum sample was assigned either into a negative class, which included the background and the bare net, or a positive class, which included everything else.

Non-metric multidimensional scaling (NMS) was used to visualize relationships between epiphyte community composition and the explanatory variables (study sites in species space). Abundance of each species was determined as its frequency on the six subplots analysed from each site. Before the analysis all epiphytes that occurred on fewer than two sites were removed resulting in a data matrix of 25 epiphyte taxa $\times$ 
Fig. 2. Effect of wind direction of epiphyte cover (bars) and biomass (see legend) on subplots, and total numbers of liverwort and macrolichen species on plots (nets) after four years in Ngangao (lower montane forest) and on Mt. Vuria (upper montane forest). Each site had two nets on the same rack, one facing upwind and the second facing downwind.
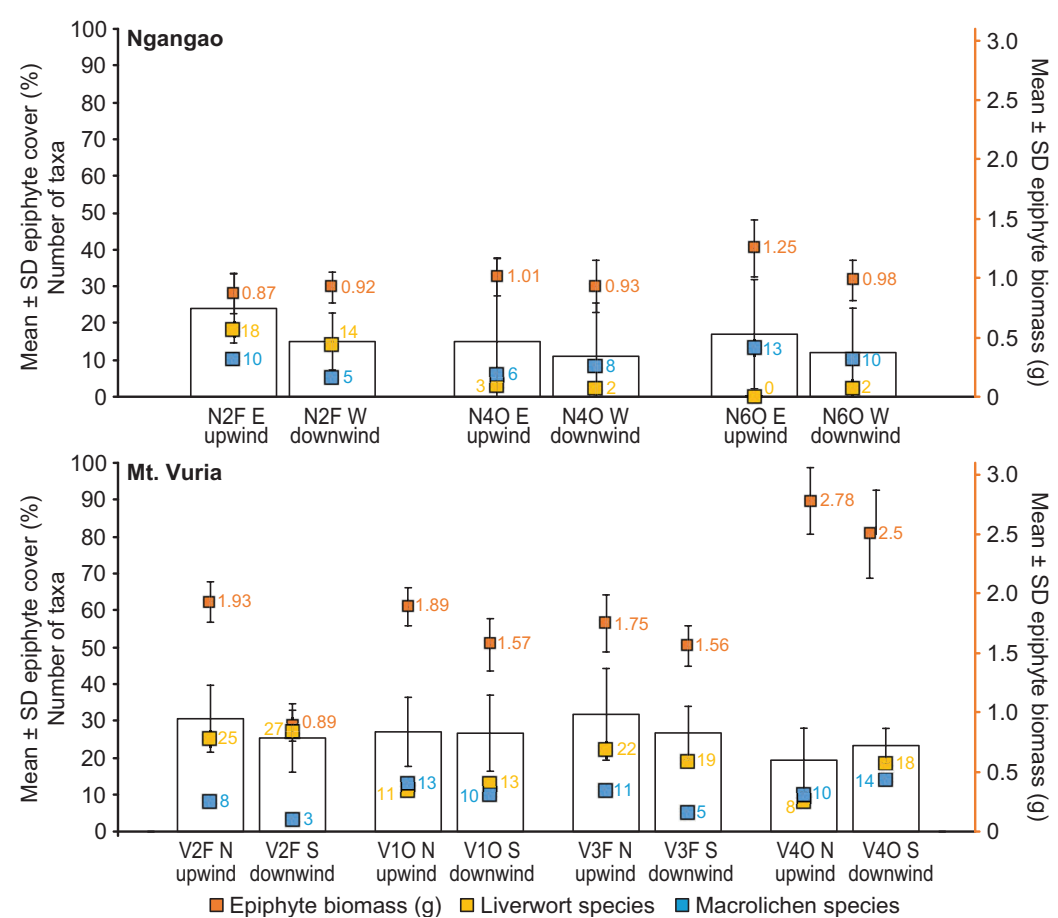

14 fog nets. The matrix was relativized by species sums of squares to de-emphasize clustering based on total abundance alone. The ordination was performed using PC-ORD ver. 6.15 (McCune \& Mefford 2011), the quantitative version of Sørensen's distance measure, 500 iterations, and random starting coordinates. The program was run in the autopilot mode (thorough) to ensure that the obtained minimum stress was not a local minimum. A two-dimensional ordination of the data matrix was produced after determining that higher dimensional solutions did not substantially reduce stress. The stability of the solution was examined by plotting stress vs. iteration number, and the probability that a similar final stress could have been obtained by chance was determined using a Monte Carlo test. Explanatory variables were superimposed on the resulting ordination using a joint plot, based on correlations of variables with the axes of the community ordination. For visual clarity, the ordination was rigidly rotated to load liverwort diversity on the vertical axis. Variance explained was expressed by the coefficient of determination between the Euclidean distances in the ordination space and the Sørensen's distances in the original species space.

\section{Results}

We found clear differences in epiphyte cover and biomass between the nets placed in the lower and upper montane forests (Figs. 1 and 2). The mean epiphyte cover of the subplots in the lower montane forest was $16 \%$, while the corresponding value for the subplots in the upper montane forest was $26 \%$. The average dry weight of epiphytes on subplots from the lower montane forest was about half of that in the upper montane forest ( $0.99 \mathrm{~g} v s .1 .86 \mathrm{~g}$ ).

There were clear differences in epiphyte species richness between the two forest types (Table 2). The total number of epiphytic liverwort species found on nets in the lower montane forest was about half of that recorded from the upper montane forest (20 vs. 39). The liverwort species in the two forest types belong mostly to Lejeuneaceae, the most dominant family of leafy liverworts throughout the humid tropics (Gradstein 1995). Four of them represented floristic novelties for the region: Acanthocoleus chrysophyllus (upper montane forest) and Diplasiolejeunea kraussiana (lower montane forest) were new to Kenya, while Acrolejeunea emergens and 
Diplasiolejeunea cavifolia (both in lower montane forest) were new to the Taita Hills (Enroth et al. 2019). The difference in the epiphytic lichen species diversity between lower and upper montane forests was less pronounced, with a total of 18 and 21 macrolichen taxa recorded from the nets in the former and latter locations, respectively. Epiphytic crustose lichens and algae were abundant and their highest cover was on the nets in the lower montane forest, with only few other epiphytes present. Interestingly, not a single epiphytic moss species was able to colonise the plastic nets in four years, despite the fact that epiphytic mosses are abundant particularly in the upper montane forest.

When comparing plots within each forest type, we found clear differences between the plots under dense forest canopy and in more open locations (Figs. 1 and 2) with epiphyte cover being greater on subplots under the canopy than the ones at more open sites (Fig. 2). However, epiphyte biomass showed an opposite pattern: the mean dry weight of epiphytes on subplots at open sites was clearly greater than that under dense canopy (Fig. 2). This reflected a major difference in epiphyte community composition: the epiphyte cover at shady sites was dominated by the relatively light liverworts, while open sites were dominated by the heavier lichens. Similar was found regarding species diversity: there were more liverwort species and fewer macrolichen species on plots under canopy than on plots at open sites.

We also compared epiphyte cover and biomass between the nets facing the wind and thus more exposed to rain and fog, and the nets facing downwind and thus likely to receive less moisture. The epiphyte cover and biomass were usually greater on the wind-facing that on the downwind nets (Fig. 2), although this difference

Table 2. Dominant non-vascular epiphytes that colonised plastic nets (plots) placed for four years in Ngangao (lower montane forest) and Mt. Vuria (upper montane forest) in the Taita Hills. Frequencies (Freq) are based on species occurrence on all subplots $(n=42$ )/all plots (Ngangao $n=6$, Mt. Vuria $n=8$ ) at each site. Correlations of epiphyte taxa with the ordination axes are shown in columns 4 and 5 (see also Fig. 3).

\begin{tabular}{|c|c|c|c|c|}
\hline \multirow[t]{2}{*}{ Epiphyte taxon } & \multicolumn{2}{|c|}{ Frequency } & \multicolumn{2}{|c|}{ Axis } \\
\hline & Ngangao & Mt. Vuria & vertical & horizontal \\
\hline Heterodermia sp. $A^{\star \star}$ & $33 / 100$ & $45 / 88$ & -0.371 & 0.297 \\
\hline Heterodermia leucomelos (s. lato) ${ }^{\star *}$ & $26 / 83$ & $43 / 88$ & -0.486 & 0.404 \\
\hline Lejeunea flava* & $14 / 50$ & $48 / 100$ & 0.885 & 0.010 \\
\hline Metzgeria furcata* & $17 / 50$ & $40 / 88$ & 0.703 & -0.226 \\
\hline Normandina pulchella & $12 / 50$ & $40 / 88$ & 0.536 & 0.548 \\
\hline Cololejeunea minutissima* & $19 / 83$ & $31 / 100$ & 0.254 & -0.371 \\
\hline Colura tenuicornis* & $7 / 33$ & $42 / 100$ & 0.441 & 0.376 \\
\hline Microlejeunea africana* & $14 / 50$ & $33 / 75$ & 0.796 & -0.122 \\
\hline Heterodermia comosa** & $31 / 100$ & $14 / 50$ & -0.766 & -0.174 \\
\hline Teloschistes sp. ${ }^{\star \star}$ & $12 / 33$ & $29 / 63$ & -0.247 & 0.640 \\
\hline Phaeophyscia cf. ${ }^{* *}$ & $24 / 83$ & not found & - & - \\
\hline Candelaria concolor/fibrosa ** & $17 / 50$ & not found & - & - \\
\hline Cololejeuna occidentalis* & $12 / 33$ & not found & - & - \\
\hline Cheilolejeunea rotundistipula* & $7 / 33$ & not found & - & - \\
\hline Frullania ericoides ${ }^{\star}$ & $5 / 33$ & not found & - & - \\
\hline Metzgeria consanguinea* & not found & $48 / 100$ & - & - \\
\hline Drepanolejeunea physaefolia* & not found & $40 / 75$ & - & - \\
\hline Lejeunea tabularis* & not found & $36 / 75$ & - & - \\
\hline Usnea sp.** & not found & $26 / 50$ & - & - \\
\hline Leptogium cf. "cyanescens" ** & not found & $19 / 50$ & - & - \\
\hline
\end{tabular}

${ }^{*}=$ liverwort, ${ }^{* *}=$ macrolichen. 
Fig. 3. NMS-ordination of 14 plots (large symbols, Up = upwind, Down = downwind) at seven study sites (large black circles $=$ shady sites, large grey circles = open sites) and epiphyte species (small black circles = liverworts, small grey circles = lichens) in epiphyte species space. Correlations of dominant epiphyte taxa with the two ordination axes are given in Table 2.

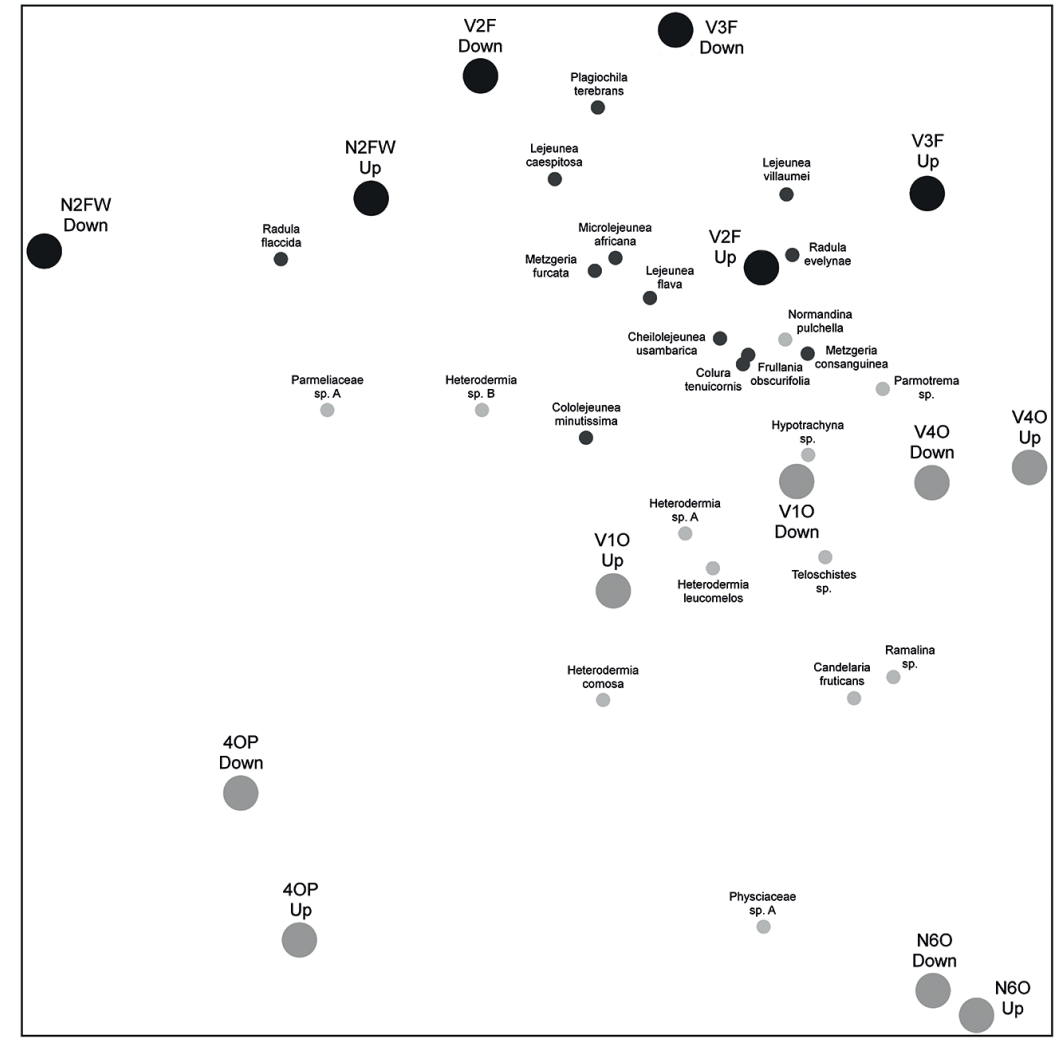

was not statistically significant $(t$-test; cover $p=$ 0.355 and biomass $p=0.386$ ).

Previously described differences in epiphyte community composition between forest types were visualised using the NMS ordination (Fig. 3). The two axes explained 91\% of the community variation. After rotation, 79\% of this was explained by the vertical axis, aligned with liverwort diversity $(r=0.907)$. The horizontal axis correlated positively with elevation $(r=0.596)$ and epiphyte cover $(r=0.690)$, and negatively with fog deposition (6-month total) $(r=-0.836)$ and lichen diversity $(r=-0.402)$. The vertical axis, representing $12 \%$ of community variation, was positively correlated with epiphyte biomass $(r=0.439)$ and lichen diversity $(r=0.375)$. Of the dominant epiphyte species, Metzgeria furcata and two Lejeunea species were strongly associated with shady sites, while Heterodermia comosa and several other lichens clearly preferred open sites (Table 2).

\section{Discussion}

Using polyethene nets, we were able to study the establishment and subsequent growth of epiphytic lichens and liverworts during four years. The period is long compared with periods used in previous comparable studies (Coley et al. 1993, Sanders \& Lücking 2002). Rich epiphyllous bryophyte communities of humid and shady tropical forests can develop during the typical lifespan of an evergreen leaf, which is 2-4 years (Gradstein \& Pócs 1989). Therefore, we are confident that the period we used was sufficiently long to capture the dynamics of diversity and biomass of epiphyllous taxa colonizing the nets.

The results provided new insights into epiphyte colonisation and revealed habitat specific differences in the colonisation success of different groups of epiphytes. After four years, there was already much variation in epiphyte community composition, partly driven by clear differences in abiotic conditions between forest types, but presumably also by biotic factors, 
such as spatial and temporal differences in propagule rain.

In tropical montane forests, the abundance of epiphytic bryophytes and lichens tends to increase with increasing elevation and also major changes in epiphyte community composition are observed along elevation gradients (Enroth 1990, Frahm \& Gradstein 1991, Wolf 1993a, Kürschner et al. 1999, Nadkarni \& Solano 2002, Hietz 2010, Santos \& Costa 2010, Ah-Peng et al. 2017). Our results are in line with these findings. Upper montane forests tend to receive ample precipitation in form of rain and frequently also fog, which is benefitial to many nonvascular epiphytes. High cover of epiphytic bryophytes is consequently a useful physiognomic feature for identifying upper montane 'mist forests' or 'mossy forests' (e.g. Frahm \& Gradstein 1991, Freiberg \& Freiberg 2000, Bruijnzeel et al. 2010, Slack 2011).

In overall species composition, the epiphyte communities of our nets bear conspicuous resemblance to Diplasiolejeunea pauckertii-Brachiolejeunea laxifolia epiphyte community previously described from Colombian montane forests (Wolf 1993b). This Andean community type is a species-rich outer canopy community dominated by liverworts and foliose lichens, typically found between 1980 and $3190 \mathrm{~m}$ a.s.l., and best developed around $2500 \mathrm{~m}$ a.s.l. Common lichen and liverwort species shared with Taita include Normandina pulchella, Heterodermia leucomelos, $H$. comosa, Lejeunea flava and Colura tenuicornis. Interestingly, mosses are relatively rare also in the Andean community (Wolf 1993b).

In the Taita Hills, the epiphyte diversity, particularly of the liverworts, was consistently higher in the upper montane forest. High humidity has been shown to be one of the most important factors for the successful colonisation and subsequent development of epiphytic bryophytes (Pócs 1977). The abundance of nonvascular epiphytes in tropical upper montane forests is generally explained by the combination of favourable moisture conditions, ample light and a relatively cool thermal conditions (Pócs 1982, Zotz 1999, Zotz et al. 2003, León-Vargas et al. 2006, Malombe et al. 2016). Most epiphytic lichens and bryophytes photosynthesize only when hydrated, and in lowland forests favour- able periods of hydration do not necessarily last long. In the deep shade of tropical lowland rainforests, the detrimental combination of excessive moisture and heat coupled with insufficient light for photosynthesis prevents the establishment of many epiphytic bryophytes and lichens (Zotz \& Schleicher 2003, Lakatos et al. 2006, Bader et al. 2013, Wagner et al. 2013).

Most of the liverwort species found in both forest types are facultative epiphytes, such as Colura tenuicornis, Lejeunea flava and Metzgeria furcata. Obligatory epiphyllous species are fewer, for example, Cololejeuna occidentalis. This indicates that the nets, as a substrate for epiphyllous species, are not directly comparable with living leaves.

High reproductive output, as indicated by the frequent presence of sporophytes in the monoecious liverworts Lejeunea flava and L. tabularis, or by the common and often abundant production of asexual propagules such as gemmae in the dioecious liverwort Metzgeria furcata or soredia in the lichens Heterodermia comosa and Normandina pulchella, most likely are an important determining factor for the successful dispersal and establishment of these epiphytes. It may also be an important element in explaining chronsequence patterns of the epiphyte communities, as predicted by Sierra et al. (2019) for epiphyllous bryophytes. In our data set, the frequency of common, effectively dispersing species was usually rather equal on up- and downwind nets at each site, largely explaining the often conspicuous pairing of the nets in the ordination (Fig. 3 and Table 2).

Confirming the results of many previous studies (e.g. Sporn et al. 2010, Benítez et al. 2015), we demonstrated that in both forest types differing in elevation, epiphytic liverworts were clearly more abundant on the nets at the shady sites, while epiphytic lichens and algae preferred open sites. This is linked to differences in the ecophysiological responses to light availability of these two groups of epiphytes: canopy reduces the amount of photosynthetically active light and affects its spectral quality, and this is known to play an important role in the habitat ecology of many epiphytic lichens and bryophytes (e.g. Barkman 1958, Rikkinen 1995, 1997, Lange et al. 2004, Rosabal et al. 2010, Mota de Oliveira \& ter Steege 2015, 
Campos et al. 2019). Many bryophytes are best adapted to photosynthesize at relatively low light levels. For example, Marschall and Proctor (2004) showed that the saturation of photosynthesis of most bryophytes occurs at around $20 \%$ of full sunlight, and the value is usually lower for liverworts than in mosses.

Malombe et al. (2016) found that the epiphyllous-bryophyte species richness and distribution within three indigenous forests in the Taita Hills did not correlate directly with the distance from the forest edge but depended on small-scale habitat variables such as available substrate, sunlight exposure, and canopy structure, which shows that there are several factors controlling species distribution. Epiphytic macrolichens tend to be most diverse and abundant in habitats that combine high atmospheric humidity with moderate levels of light (e.g. Sillett et al. 2000, Zotz \& Schleicher 2003, Antoine \& McCune 2004, Jovan \& McCune 2005, Gauslaa et al. 2006, 2007, Geiser \& Neitlich 2007).

When comparing the pairs of plastic nets mounted on the same frame, one facing upwind and second downwind, in most cases epiphytes grew better and formed more diverse communities on the upwind nets, reflecting the beneficial role of precipitation (fog and rainwater) transported by wind and captured by the net and its epiphytes. This interpretation was supported by the fact that the effect of wind exposure was most evident at open sites and reduced inside the forest, where air movement is generally obstructed by vegetation (Kruijt et al. 2000, Muñoz et al. 2004, Mota de Oliveira \& ter Steege 2015). It is also possible that epiphyte propagules carried by the wind reached upwind nets more effectively than downwind nets, and also this was reflected in epiphyte cover and community composition.

Finally, it was interesting to find that no mosses were able to colonise the nets during the four years of the study. Our previous transplant studies demonstrated that the epiphytic moss Orthostichella rigida can more than double its initial weight within one year in the moist upper montane forests of Mt. Vuria (Stam et al. 2017). Orthostichella rigida is dioicous and rarely produces sporophytes and thus spores. As also several other epiphytic moss species are abundant and grow rapidly in the same habitat, their total absence from our nets most likely reflects dispersal limitation. We assume that these pendant mosses do not primarily disperse by spores or small vegetative propagules such as gemmae, but by relatively large fragments, which do not easily become attached to vertical nets. It could also be that, as compared with many epiphytic liverworts, it takes much longer for pendant mosses to colonise a substrate. Many epiphytic liverworts produce gemmae abundantly while others are commonly fertile. This apparent contrast between different groups of epiphytic bryophytes should be investigated more as the relative importance of habitat quality and dispersal potential in limiting species distribution is an important and much debated topic in bryophyte and lichen ecology (Hutsemeke et al. 2008, Mota de Oliveira et al. 2009, Mota de Oliveira \& ter Steege 2015). Also, the observed difference in the cover and biomass of liverwort- and lichen-dominated epiphyte communities caused by the different surface to weight ratios deserves thought especially when choosing between cover and biomass as potential indicators of epiphyte abundance.

To conclude, our study demonstrated that polyethylene nets can be effectively used to study epiphyte colonisation and community organization in tropical forests. In combination with environmental measurements this approach can provide valuable information on the effects of abiotic factors on epiphyte establishment, and of intrinsic differences in the responses of different groups of non-vascular epiphytes.

\section{Acknowledgements}

We thank the helpful staff of Taita Research Station of University of Helsinki. The research was kindly permitted by the National Council for Science and Technology, Kenya, permit no. NCST/RCD/17/012/33. We also gratefully acknowledge financial support from Svenska Kulturfonden and Svenska Litteratursällskapet (to the first author), and the Faculty of Biological and Environmental Sciences, University of Helsinki.

\section{References}

Acuña-Tarazona M., Toledo-Aceves T., Flores-Palacios A., Sosa V.J. \& Martínez M.L. 2015: Post-stripping recolonization of vascular epiphytes in cloud-forest fragments 
in Mexico. - Journal of Tropical Ecology 31: 499-508.

Ah-Peng C., Williamson Cardoso A., Flores O., West A., Wilding N., Strasberg D. \& Hedderson T.A.J. 2017: The role of epiphytic bryophytes in interception, storage, and the regulated release of atmospheric moisture in a tropical montane cloud forest. - Journal of Hydrology 548: 665-673.

Antoine M. \& McCune B. 2004: Contrasting fundamental and realized ecological niches with epiphytic lichen transplants in an old-growth Pseudotsuga forest. - Bryologist 107: 163-172.

Bader M.Y., Reich T., Wagner S., González González A.S. \& Zotz G. 2013: Differences in desiccation tolerance do not explain altitudinal distribution patterns of tropical bryophytes. - Journal of Bryology. 35: 47-56

Barkman J.J. 1958: Phytosociology and ecology of cryptogamic epiphytes. - Van Gorcum, Assen.

Benítez Á., Prieto M. \& Aragón G. 2015: Large trees and dense canopies: key factors for maintaining high epiphytic diversity on trunk bases (bryophytes and lichens) in tropical montane forests. - Forestry: An International Journal of Forest Research 88: 521-527.

Bruijnzeel L., Scatena F.N. \& Hamilton L. 2010: Tropical montane cloud forests. - Cambridge University Press, Cambridge.

Campos L.V., Mota de Oliveira S., Benavides J.C., Uribe M.J. \& ter Steege H. 2019: Vertical distribution and diversity of epiphytic bryophytes in the Colombian Amazon. - Journal of Bryology 41: 328-340.

Chen L., Liu W.-Y. \& Wang G.-S. 2010: Estimation of epiphytic biomass and nutrient pools in the subtropical montane cloud forest in the Ailao mountains, southwestern China. - Ecological Research 25: 315-325.

Coley P.D., Kursar T.A. \& Machado J.-L. 1993: Colonization of tropical rain forest leaves by epiphylls: effects of site and host plant leaf lifetime. - Ecology 74: 619-623.

Enroth J. 1990: Altitudinal zonation of bryophytes on the Huon Peninsula, Papua New Guinea. A floristic approach, with phytogeographic considerations. Tropical Bryology 2: 61-90.

Enroth J., Nyqvist P., Malombe I., Pellikka P. \& Rikkinen J. 2013: Additions to the moss flora of the Taita Hills and Mount Kasigau, Kenya. — Polish Botanical Journal 58: 495-510.

Enroth J., Pócs T., He X., Nyqvist P., Stam Å., Malombe I. \& Rikkinen J. 2019: An annotated checklist for the bryophytes of Taita Hills region, Kenya. - Acta Musei Silesiae, Scientiae Naturales 68: 53-66.

Esseen P.-A. \& Renhorn K.-E. 1998: Edge effects on an epiphytic lichen in fragmented forests. - Conservation Biology 12: 1307-1317.

Foster P. 2001: The potential negative impacts of global climate change on tropical montane cloud forests. Earth-Science Reviews 55: 73-106.

Frahm J.-P. \& Gradstein S.R. 1991: An altitudinal zonation of tropical rain forests using bryophytes. - Journal of Biogeography 18: 669-678.

Freiberg M. \& Freiberg E. 2000: Epiphyte diversity and biomass in the canopy of lowland and montane forests in Ecuador. - Journal of Tropical Ecology 16: 673-688.
Gauslaa Y., Lie M., Solhaug K.A. \& Ohlson M. 2006: Growth and ecophysiological acclimation of the foliose lichen Lobaria pulmonaria in forests with contrasting light climates. - Oecologia 147: 406-416.

Gauslaa Y., Palmqvist K., Solhaug K.A., Holien H., Hilmo O., Nybakken L., Myhre L.C. \& Ohlson M. 2007: Growth of epiphytic old forest lichens across climatic and successional gradients. - Canadian Journal of Forest Research 37: 1832-1845.

Geiser L.H. \& Neitlich P.N. 2007: Air pollution and climate gradients in western Oregon and Washington indicated by epiphytic macrolichens. - Environmental Pollution 145: 203-218.

Gignac L.D. 2001: Bryophytes as indicators of climate change. - Bryologist 104: 410-420.

Gómez González D.C., Quiel R.C., Zotz G. \& Bader M. 2017: Species richness and biomass of epiphytic vegetation in a tropical montane forest in Western Panama. Tropical Conservation Science 10: 10-17.

Gradstein S.R. 1992: The vanishing tropical rain forest as an environment for bryophytes and lichens. - In: Bates J.W. \& Farmer A.R. (eds.), Bryophytes and lichens in a changing environment: 232-256. Clarendon Press, Oxford.

Gradstein S.R. 1995: Diversity of Hepaticae and Anthocerotae in montane forests of the tropical Andes. - In: Churchill S.P., Balslev H., Forero E. \& Luteyn J.L. (eds.), Biodiversity and conservation of neotropical montane forests: 321-334. New York Botanical Garden Press, New York.

Gradstein S.R. \& Pócs T. 1989: Bryophytes. — In: Lieth H. \& Werger M.L.A. (eds.), Tropical rainforest ecosystems: 311-325. Elsevier, Amsterdam.

Hietz P. 2010: Ecology and ecophysiology of epiphytes in tropical montane cloud forests. - In: Bruijnzeel L., Scatena F.N. \& Hamilton L. (eds.), Tropical montane cloud forests: science for conservation and management: 68-76. Cambridge University Press, Cambridge.

Hutsemekers V., Dopagne C. \& Vanderpoorten A. 2008: How far and how fast do bryophytes travel at the landscape scale? - Diversity and Distributions 14: 483-492.

Jácome J., Gradstein S.R. \& Kessler M. 2011: Responses of epiphytic bryophyte communities to simulated climate change in the tropics. - In: Tuba Z., Slack N.G. \& Stark L.R. (eds.), Bryophyte ecology and climate change: 191-207. Cambridge University Press, Cambridge.

Jovan S. \& McCune B. 2005: Air-quality bioindication in the greater Central Valley of California, with epiphytic macrolichen communities. - Ecological Applications 15: 1712-1726.

Kruijt B., Malhi Y., Lloyd J., Norbre A.D., Miranda A.C., Pereira M.G.P., Culf A. \& Grace J. 2000: Turbulence statistics above and within two Amazon rain forest canopies. - Boundary-Layer Meteorology 94: 297-331.

Kürschner H., Wolfgang F. \& Parolly G. 1999: Patterns and adaptive trends of life forms, life strategies and ecomorphological structures in tropical epiphytic bryophytes a pantropical synopsis. - Nova Hedwiga 69: 73-99.

Lakatos M., Rascher U. \& Büdel B. 2006: Functional characteristics of corticolous lichens in the understory of a tropical lowland rain forest. - New Phytologist 172: 
679-695.

Lange O.L., Büdel B., Meyer A., Zellner A. \& Zotz G. 2004: Lichen carbon gain under tropical conditions water relations and $\mathrm{CO}_{2}$ exchange of Lobariaceae species of a lower montane rainforest in Panama. - Lichenologist 36: 329-342.

León-Vargas Y., Engwald S. \& Proctor M.C.F. 2006: Microclimate, light adaptation and desiccation tolerance of epiphytic bryophytes in two Venezuelan cloud forests. - Journal of Biogeography 33: 901-913.

Malcolm J.R., Liu C., Neilson R.P. Hansen L. \& Hannah L. 2006: Global warming and extinction from biodiversity hotspots. - Conservation Biology 20: 438-548.

Malombe I., Matheka K.W., Pócs T. \& Patiño J. 2016: The ecological response of epiphyllous bryophytes to human-induced edges in Afromontane fragmented forests. - Journal of Bryology 38: 33-46.

Marschall M. \& Proctor M.C.F. 2004: Are bryophytes shade plants? Photosynthetic light Responses and proportions of chlorophyll $a$, chlorophyll $b$ and total carotenoids. Annals of Botany 94: 593-603.

McCune B. \& Mefford M.J. 2011: PC-ORD: multivariate analysis of ecological data, version 6.15. - MjM Software, Gleneden Beach.

McCune B., Derr C.C., Muir P.S., Shirazi A., Sillett S.C. \& Daly W.J. 1996: Lichen pendants for transplant and growth experiments. - Lichenologist 28: 161-169.

Mota de Oliveira S. \& ter Steege H. 2015: Bryophyte communities in the Amazon forest are regulated by height on the host tree and site elevation. - Journal of Ecology 103: 441-450.

Mota de Oliveira S., ter Steege H., Cornelissen J.H.C. \& Gradstein S.R. 2009: Epiphytic bryophyte communities in the Guianas are niche assembled. - Journal of Biogeography 36: 2076-2084.

Muñoz J., Felicímo A.M., Cabezas F., Burgaz, A.R. \& Martinez I. 2004: Wind as a long-distance dispersal vehicle in the southern hemisphere. - Science 304: 1144-1147.

Nadkarni N.M. \& Solano R. 2002: Potential effects of climate change on canopy communities in a tropical cloud forest: an experimental approach. - Oecologia 131: 580-586.

Nash T.H.III \& Olafsen A.G. 1995: Climate change and the ecophysiological response of arctic lichens. - Lichenologist 27:559-565.

Pellikka P., Lötjönen M., Siljander M. \& Lens L. 2009: Airborne remote sensing of spatiotemporal change (19552004) in indigenous and exotic forest cover in the Taita Hills, Kenya. - International Journal of Applied Earth Observation and Geoinformation 11: 221-232.

Pócs T. 1977: Epiphyllous communities and their distribution in East Africa. - Bryophytorum Bibliotheca 13: 681-713

Pócs T. 1982: Tropical forest bryophytes. — In: Smith A.J.E. (ed.), Bryophyte ecology: 59-104. Chapman \& Hall, London.

Porada P., van Stan J.T.II \& Kleidon A. 2018: Significant contribution of non-vascular vegetation to gobal rainfall interception. - Nature Geoscience 11: 563-567.

Räsänen M., Chung M., Katurji M., Pellikka P., Rinne J. \&
Katul G.G. 2018: Similarity in fog and rainfall intermittency. - Geophysical Research Letters 45: 1069110699.

Rikkinen J. 1995: What's behind the pretty colours? A study on the photobiology of lichens. - Bryobrothera 4: $1-239$.

Rikkinen J. 1997: Habitat shifts and morphological variation of Pseudevernia furfuracea along a topographical gradient. - Symbolae Botanicae Upsalienses 32: 223-245.

Rosabal D., Burgaz A. \& De la Masa R. 2010: Diversity and distribution of epiphytic macrolichens on tree trunks in two slopes of the montane rainforest of Gran Piedra, Santiago de Cuba. - Bryologist 113: 313-321.

Sala O.E., Chapin F.S.III, Armesto J.J., Berlow E., Bloomfield J., Dirzo R., Huber-Sanwald E., Huenneke L.F., Jackson R.B., Kinzig A., Leemans R., Lodge D.M., Mooney H.A., Oesterheld M., Poff N.L., Sykes M.T., Walker B.H., Walker M. \& Wall D.H. 2000: Global biodiversity scenarios for the year 2100. - Science 287: 1770-1774.

Sanders W.B. \& Lücking R. 2002: Reproductive strategies, relichenization and thallus development observed in situ in leaf-dwelling lichen communities. - New Phytologist 155: 425-435.

Santos N.D. \& Costa D.P. 2010: Altitudinal zonation of liverworts in the Atlantic Forest, southeastern Brazil. Bryologist 113: 631-645.

Sierra A.M., Toledo J.J., Allen N.S. \& Zartman C.E. 2019: Reproductive traits as predictors of assembly chronosequence patterns in epiphyllous bryophyte metacommunities. - Journal of Ecology 107: 875-886.

Sillett S.C., McCune B., Peck J.E., Rambo T.R. \& Ruchty A. 2000: Dispersal limitations of epiphytic lichens result in species dependent on old-growth forests. - Ecological Applications 10: 789-799.

Slack N.G. 2011: The ecological value of bryophytes as indicators of climate change. - In Tuba Z., Slack N.G. \& Stark L.R. (eds.), Bryophyte ecology and climate change: 3-12. Cambridge University Press, Cambridge.

Sporn S.G., Bos M.M., Kessler M. \& Gradstein S.R. 2010: Vertical distribution of epiphytic bryophytes in an Indonesian rainforest. - Biodiversity and Conservation 19: $745-760$.

Stam Å., Enroth J., Malombe I., Pellikka P. \& Rikkinen J. 2017: Experimental transplants reveal strong environmental effects on the growth of non-vascular epiphytes in Afromontane Forests. - Biotropica 49: 862-870.

Stam Å., Anttila J., Pellikka P. \& Rikkinen J. 2020: Sensitivity of tropical pendant bryophytes: results from a translocation experiment along an elevation gradient. Annales Botanici Fennici 57: 71-81.

Szczepaniak K. \& Biziuk M. 2003: Aspects of the biomonitoring studies using mosses and lichens as indicators of metal pollution. - Environmental Research 93: 221-230

Veneklaas E.J., Zagt R.J., van Leerdam A., van Ek R., Broekhoven A.J. \& Genderen M.V. 1990: Hydrological properties of the epiphyte mass of a montane tropical rain forest, Colombia. - Vegetatio 89: 183-192.

Wagner S., Zotz G., Salazar Allen N., Bader M.Y. 2013: Altitudinal changes in temperature responses of net pho- 
tosynthesis and dark respiration in tropical bryophytes. - Annals of Botany 111: 455-465.

Wolf J.H.D. 1993a: Diversity patterns and biomass of epiphytic bryophytes and lichens along an altitudinal gradient in the northern Andes. - Annals of the Missouri Botanical Garden 80: 928-960.

Wolf J.H.D. 1993b: Epiphyte communities of tropical montane rain forests in the northern Andes II. Upper montane communities. - Phytocoenologia 22: 53-103.

Zotz G. 1999: Altitudinal changes in diversity and abundance of non-vascular epiphytes in the tropics: an ecophysiological explanation. - Selbyana 20: 256-260.

Zotz G. \& Schleicher T. 2003: Growth and survival of the foliose lichen Parmotrema endosulphureum in the lowland tropics of Panama. - Ecotropica 9: 39-44.

Zotz G., Schultz S. \& Rottenberger S. 2003: Are tropical lowlands a marginal habitat for macrolichens? Evidence from a field study with Parmotrema endosulphureum in Panama. - Flora - Morphology, Distribution, Functional Ecology of Plants 198: 71-77. 